\title{
Phase Transformations in an AISI 410S Stainless Steel Observed in Directional and Laser-induced Cooling Regimes
}

\author{
Milton Sergio Fernandes de Lima ${ }^{a *}$, Ana Maria do Espirito Santo ${ }^{\mathrm{b}}$ \\ aInstituto de Estudos Avançados - IEAv, Centro Técnico Aeroespacial - CTA, \\ CEP 12228-970, São José dos Campos, SP, Brazil \\ ${ }^{\mathrm{b}}$ Departamento de Ciências Exatas e da Terra, Instituto de Ciências Ambientais, \\ Químicas e Farmacêuticas, Universidade Federal de São Paulo - UNIFESP, \\ Campus Diadema, CEP 09972-270, Diadema, SP, Brazil
}

Received: March 2, 2011; Revised: December 7, 2011

\begin{abstract}
The applications of the chromium ferritic stainless steel AISI 410S have been considerably increased in the last years in many technical fields as chemical industries and oil or gas transportation. However, the phase transformation temperatures are, currently, unknown for this alloy. The aim of this work is to determine the alpha to gamma transformation temperatures of the AISI 410S alloy in different cooling conditions and to analyze them using continuous cooling theory. In order to achieve different cooling rates and thermal conditions, two complementary techniques were used: Bridgman furnace crystal growth and laser remelting technique. The measured solidification temperature was around 1730 and $1750 \mathrm{~K}$. Plate-like and dendritic austenite precipitates were obtained in solid-state phase using growth rates between 5 and $10 \mu \mathrm{m} / \mathrm{s}$ in directional growth experiments. Only plate-like austenite phase was observed in the experiments using growth rates above $100 \mu \mathrm{m} / \mathrm{s}$. The appearance of dendrites, with the consequent segregation of the elements, can be previously determined by the microstructure modeling currently proposed. Massive austenite can be produced from 0.3 to $10 \mathrm{~mm} / \mathrm{s}$ rates at temperatures between $1100-1300 \mathrm{~K}$. The structure might be less sensitive to corrosion because this phase is produced without microsegregation.
\end{abstract}

Keywords: continuous cooling theory, directional solidification, Bridgman, laser remelting

\section{Introduction}

The applications of chromium ferritic stainless steels have been considerably increased in the last years in many technical fields as chemical industries and oil or gas transportation. Thanks to the combination of its highcorrosion resistance and good mechanical properties ${ }^{1}$, these alloys can be found in different environments as cargo ships and external architectural facades. Currently, the industries reduce the use of strategic and costly metals, such as $\mathrm{Ni}$, and prefer metals which maintain the corrosion and mechanical properties near to that of austenitic grade stainless steels. For this, the AISI 410S (European grade 1.4003) with $10.5-12.5 \% \mathrm{Cr}$ and less than $1 \% \mathrm{Ni}$ was developed ${ }^{2,3}$.

Although, the final microstructure is known to be composed by variable amounts of ferrite and martensite, still the 410S duplex microstructure is not well understood. Especially, the effect of cooling rate on the formation of the austenite phase and the microsegregation pattern linked to the ferrite-austenite transformation are even unclear $^{4}$. It is known that AISI new requirements of the petroleum refining industry ${ }^{5-8}$ need further research about the microstructure evolution during solidification and solid-state transformations of these steels.

Most of the phase transformation studies in ferritic/ austenitic steels ${ }^{9-111}$, were based on isothermal treatments.

*e-mail: msflima@gmail.com
This method usually requires a large number of specimens for a complete description of reactions. On the other hand, crystal growth techniques like Bridgman ${ }^{12}$ can offer a very controlled way to verify the influence of processing conditions on the kinetics of phase transformations in a single sample. In this case, the growth is imposed by the continuous displacement of isotherms (isovelocity) when the sample is displaced on the vertical axis from the equipment furnace to a quenching medium. Thus, the transformation interface is constrained to assume a given growth morphology and temperature. Phase growth studies using directional solidification have been carried out by a number of authors, like Trivedi et al. for the Al-Cu system ${ }^{13}$, Lima and $\mathrm{Kurz}^{14}$ for the $\mathrm{Fe}-\mathrm{Cr}$ and $\mathrm{Fe}-\mathrm{Ni}$ systems and Jacot et al. ${ }^{15}$ for Fe-Co alloys.

Although very useful, the Bridgman method has some limitations on growth rate. In order to obtain higher growth rates than those of Bridgman, laser conduction welding can be very helpful. Laser beam scans the material surface in order to melt a small volume of it. As the metal is a good heat sink, the melted layer is resolidified just behind the melt pool, and finally, solid-state phase transformations could occur. The method produces continuous cooling at the weld centerline at speeds related to the laser beam displacement. The weld zone is tiny compared to the Bridgman case and 
the thermal gradient is consequently higher. Laser beam welding has been used to study phase transformation in a number of systems such as $\mathrm{Al}-\mathrm{Si}^{16}, \mathrm{Al}-\mathrm{Cu}^{17}, \mathrm{Fe}-\mathrm{C}^{18}$ and some multicomponent materials ${ }^{19,20}$.

The aim of this work is to determine the alpha to gamma transformation temperatures of the AISI 410S alloy for different cooling conditions and compare them with those obtained from the continuous cooling theory.

\section{Modeling Phase Transformations}

The growth theory used here has been developed for Bridgman solidification ${ }^{21,22}$ and after for laser pulsed melting ${ }^{23}$. There is good evidence that solidification models apply to solid-state phase transformations under certain carefully chosen circumstances, giving a new insight ${ }^{14}$. For this, it is necessary that, as a liquid-solid transformation, the solid-state transformation front is highly mobile and the parent phase has a larger solute diffusion coefficient than the product.

One elegant way to represent the complex interface behavior is through the steady-state interface response, IR, i.e. by the interface temperature versus growth rate for a fixed thermal gradient (Figure 1). The temperature and the related concentration of the growing interface are functions of the initial composition of the alloy, $\mathrm{C}_{0}$, of the interface velocity, $\mathrm{V}$, and the thermal gradient, $\mathrm{G}$. Figure 1a is a schematic representation of the IR for the liquid-solid transformation ${ }^{21}$. The phase diagram to the left of Figure 1a gives the reference temperatures, liquidus and solidus, for the construction of the interface response. Cells and dendrites are expected in the velocity range given by

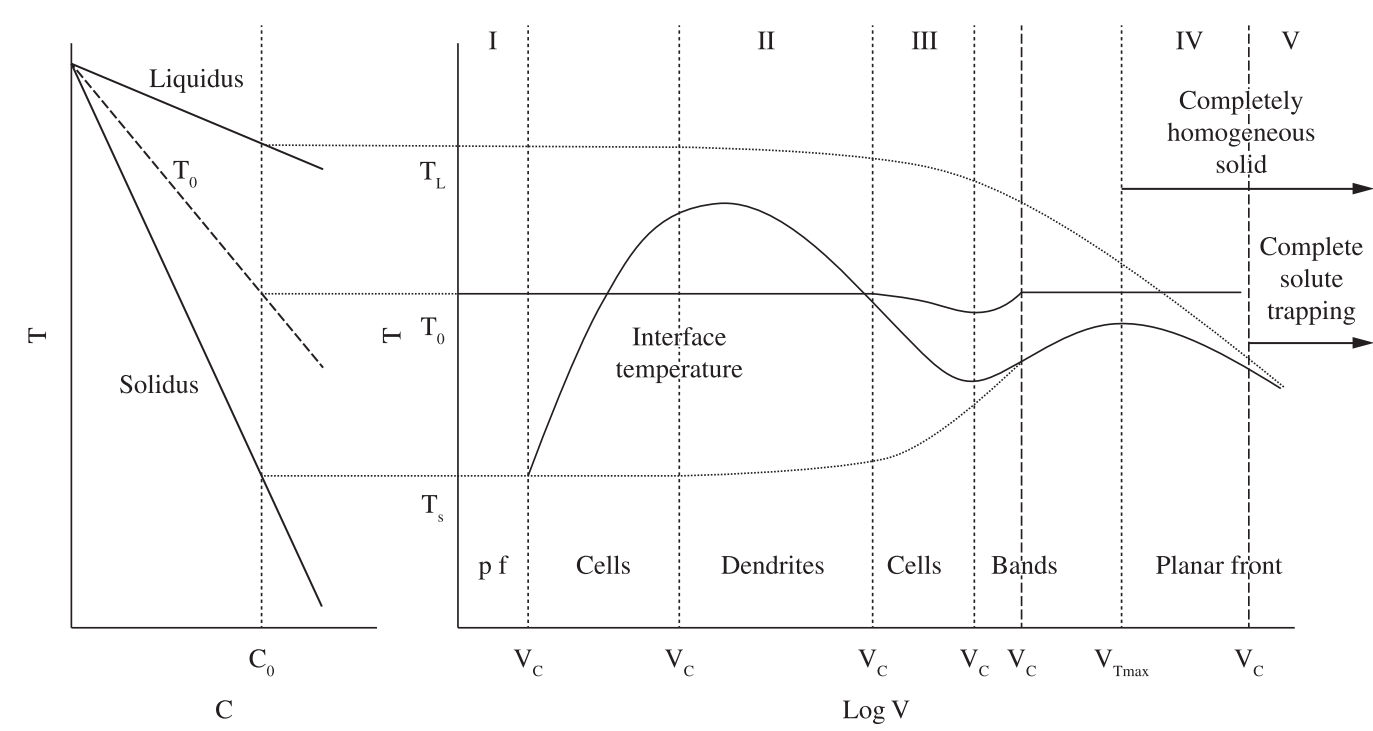

(a)

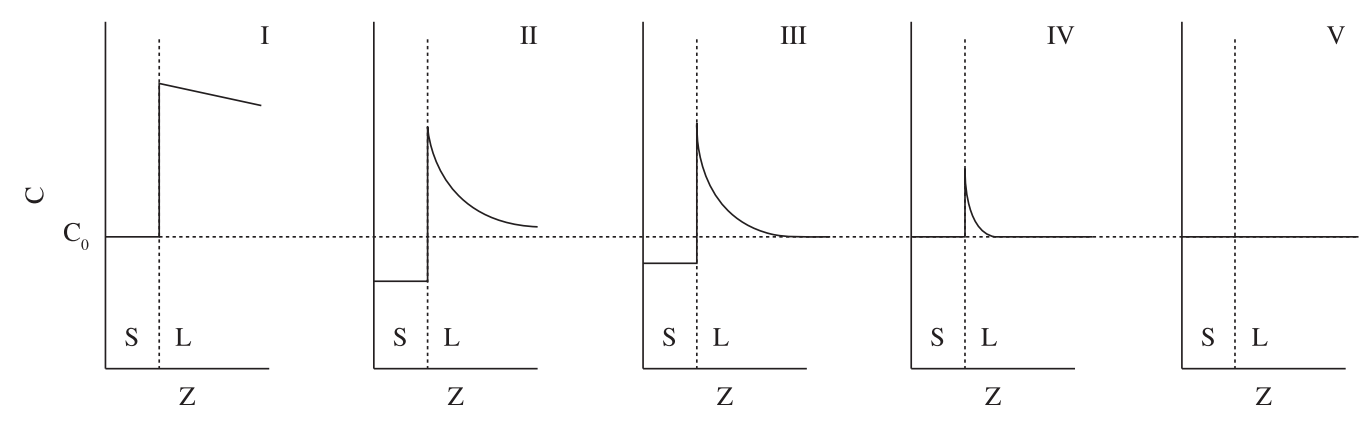

(b)
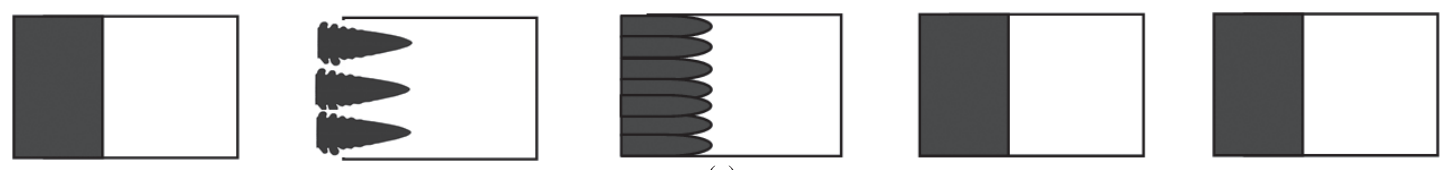

(c)

Figure 1. Schematic representation of the microstructural modeling criteria with related IR function (a) and the effect of growth speed on the solute spike (b). Schematic drawings of the interface morphology (c) are also shown. 
the limits of constitutional undercooling, $\mathrm{Vc}$, and absolute stability, Va. Plane front growth occurs below Vc and above Va (Figure 1c). Figure 1b shows the evolution of the solute spike near the interface for five representative cases for the hypothetical phase diagram (Figure 1a) with $\mathrm{k}_{\mathrm{e}}<1$. The effect of solute trapping can be seen in the reduction between the solid and liquid compositions at the interface with increasing velocity (Figure 1b), and by the decrease of the liquidus/solidus interval (Figure 1a). Cases "A", "D" and "E" represent steady-state plane front morphologies. Composition invariance is the result of any steady-state plane front growth. Therefore, case "A" corresponds to the local equilibrium, "D" to partial solute trapping, and " $\mathrm{E}$ " to complete solute trapping. The boundary layer in the liquid has amplitude $\mathrm{C}_{0} / \mathrm{k}_{\mathrm{v}}$ and a characteristic thickness of $\mathrm{D} / \mathrm{V}$.

At low velocities a planar interface is stable to perturbations if the thermal gradient is larger than the liquidus-temperature gradient at the interface (Figure 1c). The lower plane front limit is given by the constitutional undercooling criterion ${ }^{24}$ (Equation 1):

$V_{C}=\frac{\bar{G} D}{\Delta T_{0}}$

where the conductivity-weighted temperature gradient is $\overline{\mathrm{G}}=\left(\mathrm{G}_{\mathrm{S}} \kappa_{\mathrm{S}}+\mathrm{G}_{\mathrm{L}} \kappa_{\mathrm{L}}\right) /\left(\kappa_{\mathrm{S}}+\kappa_{\mathrm{L}}\right)$, with $\mathrm{G}_{\mathrm{i}}$ and $\mathrm{k}_{\mathrm{i}}$ the temperature gradient and conductivity of phase $\mathrm{i}$ (liquid and solid, respectively), D is the solute diffusion coefficient in the parent phase, and $\Delta \mathrm{T}_{0}\left(=\mathrm{T}_{1}-\mathrm{T}_{\mathrm{s}}\right)$ is the equilibrium liquidussolidus interval. When non-equilibrium conditions prevail at the transformation front, the liquidus is reduced and the solidus raises, both approaching $\mathrm{T}_{0}$. Further, at high velocities, the transformation temperature decreases due to attachment kinetic undercooling. The liquidus-solidus interval is therefore a function of the interface velocity, $\Delta \mathrm{T}_{0}(V)$. At very low velocities the liquidus-solidus interval is effectively constant while at higher V, when solute trapping begins, it decreases. For a linearized phase diagram (Equation 2):

$\Delta T_{0}(V)=T_{l}(V)-T_{s}(V)=C_{0} m_{v} \frac{\left(k_{v}-1\right)}{k_{v}}$

where $\mathrm{C}_{\mathrm{o}}$ is the alloy composition, $\mathrm{m}_{\mathrm{v}}$ is the velocity dependent non-equilibrium liquidus slope and $\mathrm{k}_{\mathrm{v}}$ is the nonequilibrium partition coefficient ${ }^{25}$. Equation 2 reduces to $\Delta \mathrm{T}_{0}$ when $\mathrm{k}_{\mathrm{v}}$ approaches the equilibrium value $\mathrm{k}_{\mathrm{e}}$.

As presented in the continuous growth model for dilute solutions $s^{26-28},{ }^{2}$ the non-equilibrium partition coefficient $\left(\mathrm{k}_{\mathrm{v}}\right)$ and non-equilibrium liquidus slope $\left(\mathrm{m}_{\mathrm{v}}\right)$ can be calculated from the equilibrium values $\mathrm{k}_{\mathrm{e}}$ and $\mathrm{m}_{\mathrm{e}}$, as (Equations 3 and 4):

$$
\begin{aligned}
& k_{v}=\frac{k_{e}+V / V_{d}}{1+V / V_{d}} \\
& m_{v}=m_{e} \frac{1-k_{v}\left[1-\ln \left(k_{v} / k_{e}\right)\right]}{1-k_{e}}
\end{aligned}
$$

where $\mathrm{V}_{\mathrm{d}}$ is the diffusion velocity across the interface that may be approximated by the ratio of the solute diffusivity across the interface $\left(D_{i}\right)$ to the thickness of that interface $\left(a_{0}\right)$.
In steady state, the plane front grows at the solidus isotherm and the interface compositions in the liquid and solid are $\mathrm{C}_{1}^{*}=\mathrm{C}_{0} / \mathrm{k}_{\mathrm{v}}$ and $\mathrm{C}_{\mathrm{s}}^{*}=\mathrm{C}_{0}$, respectively. This situation corresponds to case $A$ in Figure 1 when $k_{v}=k_{e}$. Above $V_{C}$ the interface adopts a cellular or dendritic morphology, the growth temperature $\left(\mathrm{T}^{*}\right)$ rises above the solidus and the cell/ dendrite tips incorporate less solute than $\mathrm{C}_{\mathrm{o}}$ (Figure 1b, "B" and "C"). For cellular/dendritic growth, the tip temperature, $\mathrm{T}^{*}$ is given by ${ }^{21,29}$ (Equation 5):

$T^{*}=T_{l}+C_{l}^{*}\left(m_{v}-m_{e}\right)-\frac{2 \Gamma}{R}-\frac{\bar{G} D}{V}$

where $\mathrm{T}_{1}$ is the liquidus temperature for the initial composition of the alloy, $\Gamma$ is the Gibbs-Thomson coefficient, $\mathrm{R}$ is the dendrite tip radius. The dendrite tip radius is calculated as the minimum value of $\mathrm{R}$ in the following Equation 6:

$4 \pi^{2} \Gamma+2 R \frac{P e \cdot C_{o} \cdot m_{v} \cdot\left(1-k_{v}\right) \cdot \xi_{c}}{1-\left(1-k_{v}\right) I v(P e)}+G R^{2}=0$

where $\xi_{\mathrm{c}}$ is a stability parameter, and $\mathrm{Pe}$ and $\operatorname{Iv}(\mathrm{Pe})$ are the Péclet number (=RV/2D) and Ivantsov function of Péclet, respectively ${ }^{30}$.

At high velocities, a cellular microstructure is stabilized again and the microstructure becomes finer. When the velocity reaches the upper limit diffusion becomes localized and capillary phenomena dominate so that plane-front growth reappears (case "D" of Figure 1). This occurs beyond the limit of absolute stability, $\mathrm{V}_{\mathrm{a}}$, given by ${ }^{31,32}$ (Equation 7):

$V_{a}=\frac{\Delta T_{0}(V) D}{k_{v} \Gamma}$

once plane front growth is stable again, the composition of the solid is $\mathrm{C}_{\mathrm{o}}$ and the composition of the liquid depends on the growth velocity. The solution for a planar-front is obtained from the non-equilibrium liquid composition at the interface, $\mathrm{C}_{1}{ }^{*}$, which could be calculated using ${ }^{33}$ Equation 8 .

$$
C_{l}^{*}=\frac{C_{l}^{e}}{1+\frac{k_{e}-k_{v}\left(1-\ln k_{v} / k_{e}\right)}{1-k_{e}}}
$$

where $\mathrm{C}_{1}^{\mathrm{e}}$ is the equilibrium liquidus composition.

Beyond absolute stability, when $\mathrm{dT} / \mathrm{dV}>0$, oscillatory instabilities may occur. This phenomenon, known as banding, is produced by the alternate growth of two structures $^{33,34}$. Such oscillatory structures however do not seem to form if the distribution coefficient is close to unity, as is the case of the studied alloy. In the current analyses, the plane-front temperature $\mathrm{T}_{\mathrm{p}}$ is calculated from the phase diagram with the necessary non-equilibrium corrections (Equations 3 and 4). Thus (Equation 9):

$T_{p}=T_{f}+m_{v} C_{o} / k_{v}-\Delta T_{k}$

where $T_{f}$ is the melting point of the solvent and $\Delta T_{k}$ is the atom attachment undercooling. With increasing $\mathrm{V}$, the nonequilibrium solidus temperature rises close to $\mathrm{T}_{0}$ when solute trapping becomes important (effect of second term on the RHS of Equation 9). At even higher velocities, attachment kinetics becomes the dominant mechanism (third term on the RHS of Equation 9) and the plane front temperature decreases (D and $\mathrm{E}$ in Figure 1a). 
For collision-limited growth of a rough interface, the value of the atom attachment undercooling is, to a first approximation $^{35}$ (Equation 10):

$$
\Delta T_{k}=\frac{R_{g} T_{f}}{V_{0} \Delta S_{t}} V
$$

where $\mathrm{R}_{\mathrm{g}}$ is the gas constant, $\mathrm{V}_{0}$ is the sound speed in the solid and $\Delta S_{t}$ is the molar entropy of transformation.

Up to now one considers a binary system but in most engineering cases, like the present one, the system is multicomponent. Gilgien and others ${ }^{19,22}$ extended the analyses for the multicomponent case, which can be valid as long as every solute diffuses independently. For a multicomponent alloy, the limit of constitutional undercooling is a sum of i-components. Considering a linearlized phase diagram, Equation 1 is then ${ }^{36,37}$ (Equation 11):

$V_{C}=\bar{G} \sum_{i} \frac{k_{i} D_{i}}{m_{i} C_{0, i}\left(k_{i}-1\right)}$

For a multicomponent alloy, Equations 3 and 4 must be applied for each component and the parameters become $\mathrm{k}_{\mathrm{v}, \mathrm{i}}, \mathrm{k}_{\mathrm{e}, \mathrm{i}}$, and $\mathrm{V}_{\mathrm{d}, \mathrm{i}}$. As in the case of $\mathrm{V}_{\mathrm{c}}$, the absolute stability limit must be considered as a sum over i-solutes, giving (Equation 12):

$V_{a}=\sum_{i} \frac{m_{v, i} C_{0, i}\left(k_{v, i}-1\right) D_{i}}{k_{v, i}^{2} \Gamma}$

The out-of-equilibrium liquidus slope, $\mathrm{m}_{\mathrm{v}, \mathrm{i}}$, is given by (Equation 13):

$m_{v, i}=\frac{1-k_{v, i}\left[1-\ln \left(k_{v, i} / k_{e, i}\right)\right]}{1-k_{e, i}} m_{e, i}$

The phase growth temperature during cellular and dendritic growth is the liquidus minus a undercooling. When the growth speed is below the diffusive speed $\left(\mathrm{V}<<\mathrm{V}_{\mathrm{d}}\right)$, the interface undercooling is composed by the curvature undercooling and the solute rejection undercooling. For a multicomponent alloy, the dendrite tip temperature is (Equation 14):

$$
T^{*}=T_{l}+\sum_{i} C_{l, i}^{*}\left(m_{v, i}-m_{e, i}\right)-\frac{2 \Gamma}{R}-\frac{\bar{G} D}{V}-\Delta T_{k}
$$

Where $\mathrm{T}_{1}$ is the liquidus temperature of the alloy at the initial composition, $\mathrm{C}_{1}^{*}$ is the liquid composition in contact with the dendrite tip, $\Gamma$ is the Gibbs-Thomson coefficient, $\mathrm{R}$ is the dendrite tip radius and $\Delta \mathrm{T}_{\mathrm{k}}$ is the atomic attachment undercooling.

\section{Experimental}

Swiss Steels Ltd. supplied the AISI 410S alloy in the form of a $10 \mathrm{~mm}$ diameter rolled bar. The analyzed composition is presented in Table 1 and the correspondingly phase diagram as calculated by the SSOL Thermocalc database $^{38}$ is shown in Figure 2. This phase diagram corresponds to a $\mathrm{Fe}-\mathrm{Cr}$ section for the multicomponent alloy with initial Cr-composition indicated by the dashed line. Table 2 presents additional physical-chemistry data from references 38 to 42 .
The interface thickness was considered as $2 \mathrm{~nm}$ for the solid/liquid interface ${ }^{29}$, and equal to the lattice parameter of the ferrite $(2.8 \AA)$ for the ferrite/austenite transformation. The diffusivity of others elements than $\mathrm{Cr}$ in iron were obtained in the references 39 and 7 for both liquid and ferrite phases.

The isovelocity experiments were carried out in a Bridgman furnace with a liquid metal cooling system (Ga-In-Sn alloy) for efficient quenching. Each sample was melted in a $6 \mathrm{~mm}$ I.D. alumina tube inserted in a radiation vertical furnace and lowered into the liquid metal bath at rapid rate $(33 \mu \mathrm{m} / \mathrm{s})$. When the alumina tube with the specimen penetrated about $8 \mathrm{~cm}$ into the cooling bath, the speed was reduced to the selected value. This ensured a steady state temperature profile in the specimen. In the present study the selected velocities were 5, 10 and $100 \mu \mathrm{m} / \mathrm{s}$. At a given moment, the tube was dropped into the liquid, thus producing a snapshot of the growth microstructures at high temperatures. An experiment using an alumina-encapsulated thermocouple inserted in the axis of the bar was used to evaluate the thermal profile, and

Table 1. Chemical composition, in wt. (\%), of the AISI 410S sample (Fe balance).

\begin{tabular}{cccccccccc}
\hline $\mathbf{C}$ & $\mathbf{S i}$ & $\mathbf{M n}$ & $\mathbf{P}$ & $\mathbf{S}$ & $\mathbf{N i}$ & $\mathbf{C r}$ & $\mathbf{C u}$ & $\mathbf{M o}$ & $\mathbf{V}$ \\
\hline 0.02 & 0.91 & 0.39 & 0.025 & 0.007 & 0.45 & 12.27 & 0.08 & 0.03 & 0.06 \\
\hline
\end{tabular}

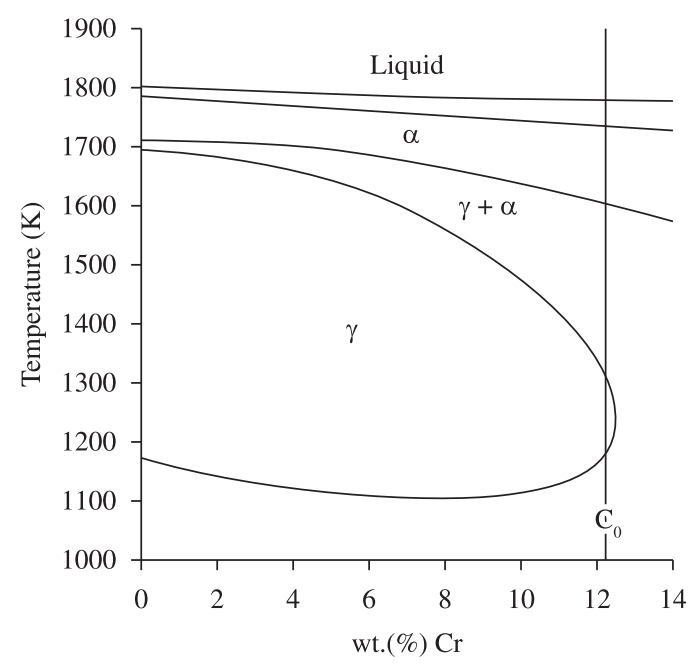

Figure 2. Pseudo-binary phase diagram of the AISI $410 \mathrm{~S}$ alloy in a $\mathrm{Fe}-\mathrm{Cr}$ section. The initial composition $\left(\mathrm{C}_{0}\right)$ is shown.

Table 2. Physical properties of the alloy for both transformations.

\begin{tabular}{lcc}
\hline & Solidification & Ferrite/austenite \\
\hline Liquidus $(\mathrm{K})$ & 1774.11 & 1587.74 \\
Solidus $(\mathrm{K})$ & 1729.26 & 1283.60 \\
$\mathrm{D}_{\mathrm{Cr}}($ solidus $)\left(\mathrm{m}^{2} / \mathrm{s}\right)$ & $3 \times 10^{-9}$ & $4.27 \times 10^{-14}$ \\
$\Gamma\left(\mathrm{m}^{-1} \mathrm{~K}^{-1}\right)$ & $1.9 \times 10^{-7}$ & $5.5 \times 10^{-6}$ \\
$\Delta \mathrm{H}\left(\mathrm{J} \cdot \mathrm{mol}^{-1}\right)$ & $11 ’ 300$ & $80^{\prime} 370$ \\
$\Delta \mathrm{S}\left(\mathrm{J} \cdot \mathrm{mol}^{-1} \cdot \mathrm{K}\right)$ & 6.4 & 6.5 \\
$\mathrm{~V}_{0}(\mathrm{~m} / \mathrm{s})$ & 2000 & 5000 \\
\hline
\end{tabular}


thus used to predict phase transformation temperatures and thermal gradient. The thermocouple experiment was carried out at $10 \mu \mathrm{m} / \mathrm{s}$.

$\mathrm{A} \mathrm{CW}-\mathrm{CO}_{2}$ laser was focused to a $0.5 \mathrm{~mm}$ spot diameter on the steel surface. The temperature history at centerline was evaluated using Rosenthal method ${ }^{44}$. The macroscopic shape of melt pool was used to calibrate the laser-steel absorption.

Microstructural analyses were carried out using optical microscopy. The samples were cut and polished using standard techniques, and subsequently electrolytically etched in an aqueous solution of $\mathrm{CuCl}_{3}$.

\section{Results}

\subsection{Bridgman growth}

Directional growth experiments produced ferrite singlecrystals with different interface microstructures in different growth speeds, Figure 3: a planar interface at $5 \mu \mathrm{m} / \mathrm{s}$, a cellular interface at $10 \mu \mathrm{m} / \mathrm{s}$, and a dendritic interface at $100 \mu \mathrm{m} / \mathrm{s}$.

The average thermal gradients were evaluated using the thermocouple experiment, giving: $18 \mathrm{~K} . \mathrm{mm}^{-1}$ for solidification and $40 \mathrm{~K} \cdot \mathrm{mm}^{-1}$ for ferrite-austenite transformation.
The average spacing between cells or dendrites was $144 \pm 8$ and $95 \pm 14 \mu \mathrm{m}$, for the samples grown at 10 and $100 \mu \mathrm{m} / \mathrm{s}$ respectively. Using this data and Equation 6, the cell/dendrite tip radii were evaluated as 5.9 and $2.6 \mu \mathrm{m}$, respectively. The solidification interfaces were concave as result of heat and solute convection in the liquid (Figure 3a). Additionally, for the $5 \mu \mathrm{m} / \mathrm{s}$ sample, the crystal presented lateral facets indicating that the crystal grown in the $<001>$ direction. The measured solidification temperatures for the three growth speeds were situated at $1730 \pm 20 \mathrm{~K}$ for the planar interface, and at $1750 \pm 20 \mathrm{~K}$ for the other two conditions. The errors are due to uncertainties on the position of the interfaces.

The first austenite precipitates were dendritic and plate-like for the growth speeds of 5 and $10 \mu \mathrm{m} / \mathrm{s}$ as can be seen in Figure 4a. In the case of $100 \mu \mathrm{m} / \mathrm{s}$, the early austenite was always plate-like. For all growth speeds the growth temperatures were situated around $1300 \mathrm{~K}$. Table 3 summarizes the observations of morphology and temperatures for the directional growth samples.

Grains, formed in lower temperatures, were partially transformed to martensite during quenching, Figure 4b. Metallographic analyses shown that the austenite precipitates have not a preferential growth direction in respect to the ferrite matrix.

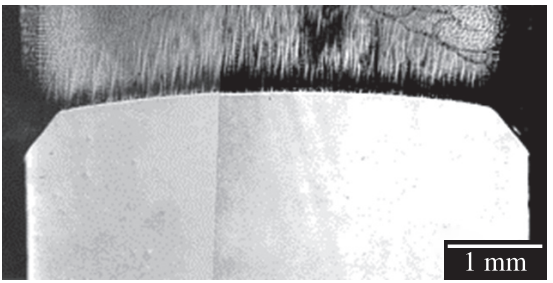

(a)

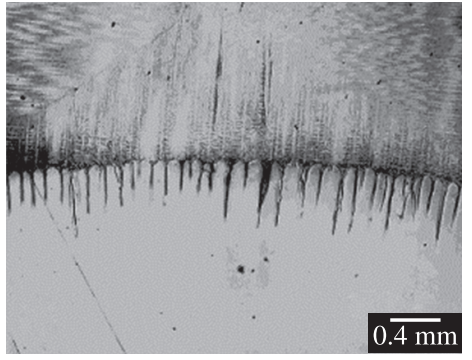

(b)

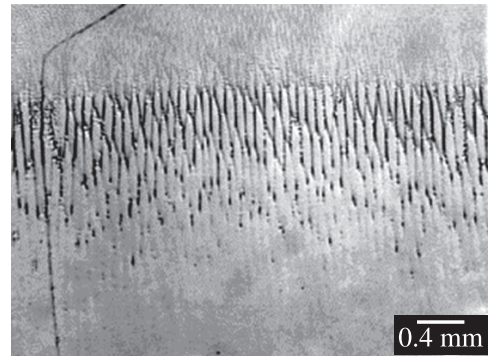

(c)

Figure 3. Bridgman samples cross-section near solid-liquid interphase. a) $5 \mu \mathrm{m} / \mathrm{s}$, b) $10 \mu \mathrm{m} / \mathrm{s}$, and c) $100 \mu \mathrm{m} / \mathrm{s}$. Growth direction is upwards.

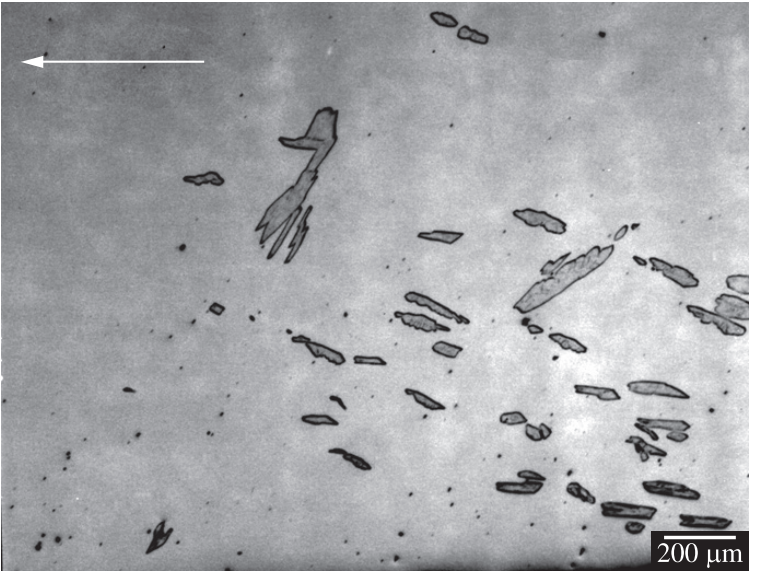

(a)

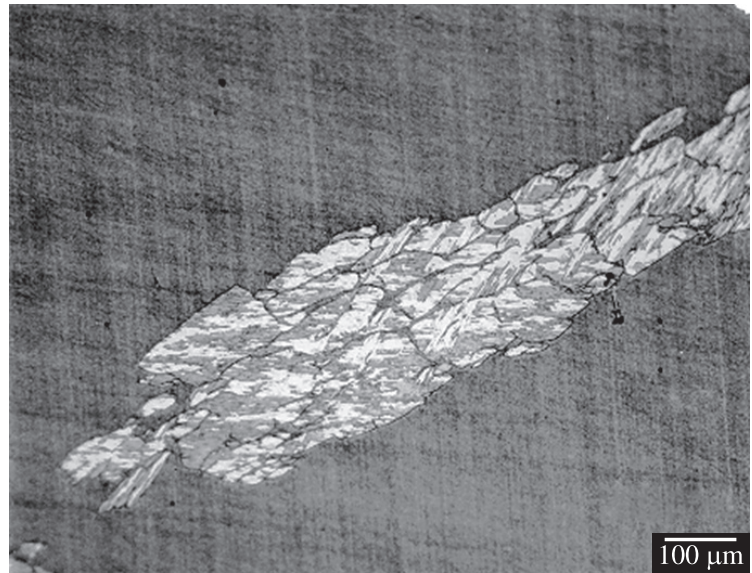

(b)

Figure 4. a) Precipitates of austenite in the ferrite matrix, Bridgman, $5 \mu \mathrm{m} / \mathrm{s}$. The arrow indicates the growth direction; b) Austenite grains partially transformed in martensite (dark phase) after quenching. 
Table 3. Summary of directional growth experiments results.

\begin{tabular}{rccccc}
\hline $\mathbf{V}(\mu \mathbf{m} / \mathbf{s})$ & \multicolumn{3}{c}{ Solidification } & \multicolumn{2}{c}{ Solid-state transformation } \\
\cline { 2 - 6 } & Morphology & $\lambda(\mu \mathbf{m})$ & $\mathbf{T}_{\text {sol }}(\mathbf{K})$ & Morphology & $\mathbf{T}_{\text {ss }}(\mathbf{K})$ \\
\hline 5 & Planar & - & $1730 \pm 20$ & Dendritic & $1250 \pm 20$ \\
10 & Cellular & 144 & $1750 \pm 20$ & Dendritic & $1330 \pm 20$ \\
100 & Dendritic & 95 & $1750 \pm 20$ & Dendritic & $1310 \pm 20$ \\
\hline
\end{tabular}

\subsection{Laser remelting}

The solidification microstructure of laser-remelted samples was dendritic forming grains, Figure 5. The grains grown to the centerline and became finer as laser scanning speed was increased. Differently of Bridgman experiments, it was not possible to measure the temperature of the dendritic front for laser remelting.

In scanning speeds between 0.3 and $10 \mathrm{~mm} / \mathrm{s}$, it was possible to observe austenite precipitates in the remelted trace. These precipitates can cross grain boundaries and were plate-like, Figures $6 a$ and b. As can be seen, the austenite precipitates can nucleate inter- or intra-granular depending on the grain boundary density of the laser track. Laser experiments from 0.3 to $0.6 \mathrm{~mm} / \mathrm{s}$ produced precipitates at the same order of temperatures of Bridgman experiments, i.e. around $1000{ }^{\circ} \mathrm{C}$, Figure 7. Above this velocity the temperature drops to reach $900{ }^{\circ} \mathrm{C}$ at $10 \mathrm{~mm} / \mathrm{s}$. Above $10 \mathrm{~mm} / \mathrm{s}$, the precipitates disappeared from the remelted trace.

\subsection{Calculations}

Solidification under Bridgman: $\mathrm{V}_{c}$ and $\mathrm{V}_{\mathrm{a}}$ were calculated giving $1.34 \mu \mathrm{m} / \mathrm{s}$ and $0.75 \mathrm{~m} / \mathrm{s}$, respectively. For the $5 \mu \mathrm{m} / \mathrm{s}$ experiment the planar interface is at solidus. For the 10 and $100 \mu \mathrm{m} / \mathrm{s}$ experiments the temperatures can be evaluated by the measured average tip radii together with Equation 7. The results are presented in Table 4.

Ferrite-austenite transformation: The interface response for the ferrite-austenite is presented in Figure 7 together with the experimental results. $\mathrm{V}_{\mathrm{c}}$ and $\mathrm{V}_{\mathrm{a}}$ were calculated giving $5.7 \times 10^{-12} \mathrm{~m} / \mathrm{s}$ and $13.3 \mu \mathrm{m} / \mathrm{s}$, respectively. Therefore, for the current steel, composition invariant transformation of ferrite into austenite (planar front) was expected above $13.3 \mu \mathrm{m} / \mathrm{s}$.

\section{Discussion}

Since the temperature near to the tube wall is higher than in the center of the tube, the liquid at periphery rises up and the liquid near the axis of the tube moves downwards. This convection will lead to a lateral rejection of solute and to a curved solid/liquid interface, Figure $3 \mathrm{a}$. In addition, this convection disrupts the solute built-up in the front of the growing interface leading to a stabilization of the interface ${ }^{13}$. This stabilization effect is reflected by an extension of planar growth range during solidification; the calculated constitutional undercooling velocity, $\mathrm{V}_{\mathrm{c}}=1.34 \mu \mathrm{m} / \mathrm{s}$, is below that evaluated by Bridgman experiments $5 \mu \mathrm{m} / \mathrm{s}<\mathrm{V}_{\mathrm{c}}<10 \mu \mathrm{m} / \mathrm{s}$.

The temperature measurements were not very precise but some general tendencies can be verified. The measured solidification temperature for planar front, $\mathrm{V}=5 \mu \mathrm{m} / \mathrm{s}$,

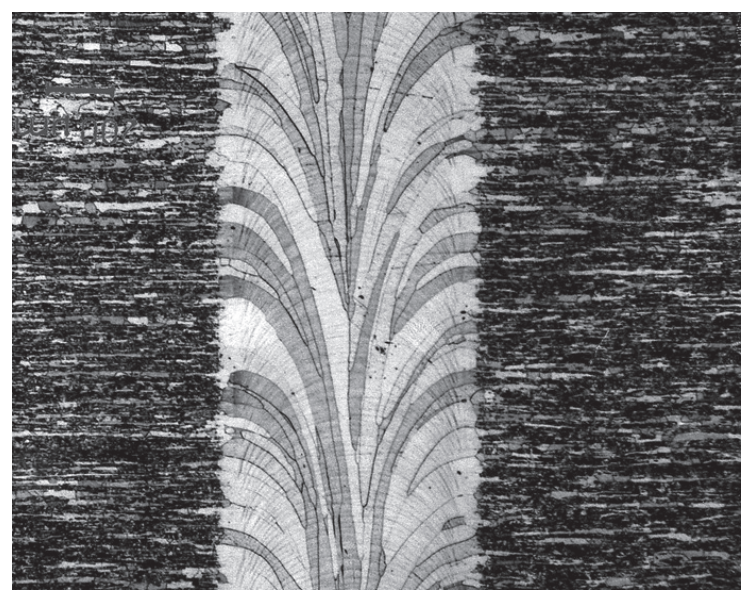

Figure 5. Upper view of a laser remelting trace at $5 \mathrm{~mm} / \mathrm{s}$. Laser displacement downwards.

was in good agreement with solidus; the measured value of solidification temperature being about $1730 \mathrm{~K}$ for a calculated solidus of $1729.26 \mathrm{~K}$. On the other hand, the other two growth temperatures, for $\mathrm{V}=10$ and $100 \mu \mathrm{m} / \mathrm{s}$, presented fairly agreement between calculations and experiments. The measured growth temperatures rest at about $1750 \mathrm{~K}$ for both 10 and $100 \mu \mathrm{m} / \mathrm{s}$ experiments, when calculated results predict 1769 and $1773 \mathrm{~K}$, respectively. This could be also linked to the errors in determining precisely the interface position since some differences could occur in the temperature history, albeit the three directional growth experiments were performed in similar conditions.

Some of the early austenite precipitates during the Bridgman experiments ( 5 and $10 \mu \mathrm{m} / \mathrm{s}$ ) presented dendritic morphology, Figure 4. Chromium segregation was observed near these dendrites ${ }^{45}$, as expected for a composition variant transformation. On the other hand, plate-like precipitates (above $100 \mu \mathrm{m} / \mathrm{s}$ ) had the same composition of the surrounding ferrite. These results are in good agreement with theoretical predictions for composition variant/ invariant austenite growth, as the calculated value of $\mathrm{V}_{\mathrm{a}}$ for ferrite-austenite transformation was $13.3 \mu \mathrm{m} / \mathrm{s}$. This fact, the absence of orientation relationship with the matrix and the characteristic of crossing grain boundaries, shown that massive austenite is obtained above $\mathrm{V}_{\mathrm{a}}$.

The austenite start temperature, as determined in the directional growth and the laser experiments were near to inferior solvus for growth speeds up to $0.6 \mathrm{~mm} / \mathrm{s}$; after this velocity the temperature drops, Figure 7. Taking the Continuous Growth Model (CGM) into account, it was expected a temperature increase due to solute trapping effect, 


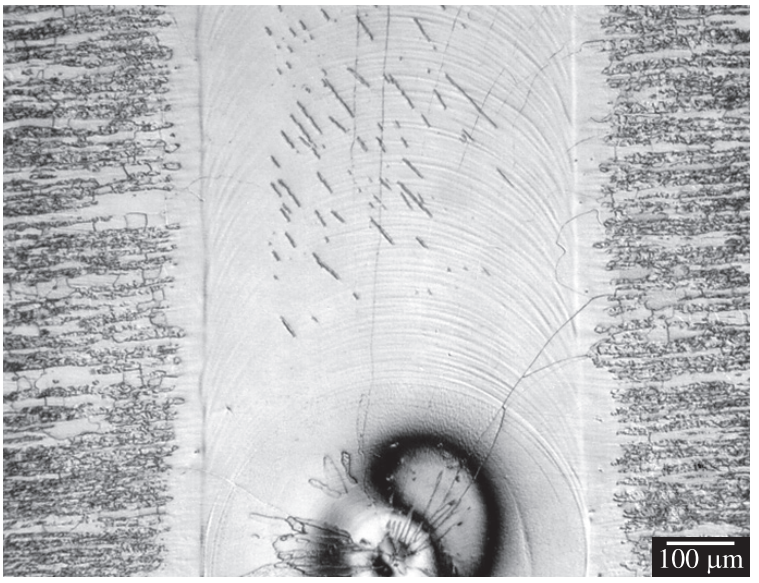

(a)

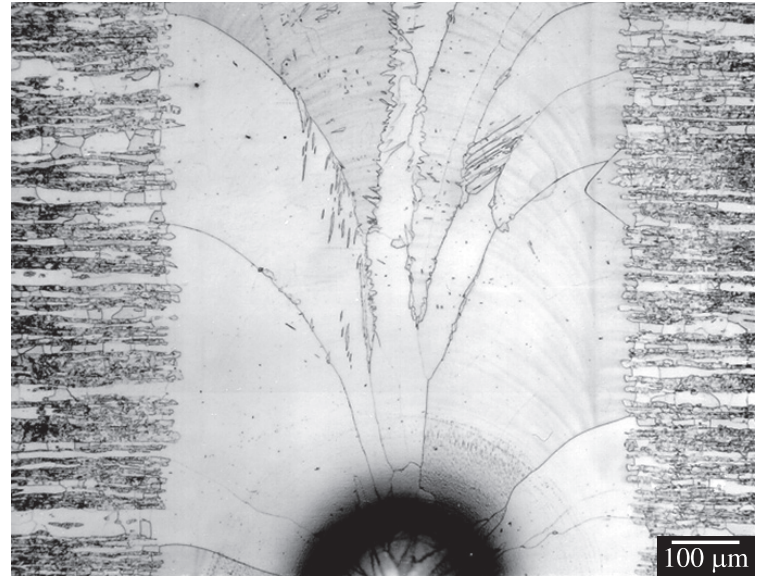

(b)

Figure 6. Laser remelted traces near to the final liquid bath position (quenching). a) $0.4 \mathrm{~mm} / \mathrm{s}$ and b) $0.6 \mathrm{~mm} / \mathrm{s}$. Laser displacement downwards.

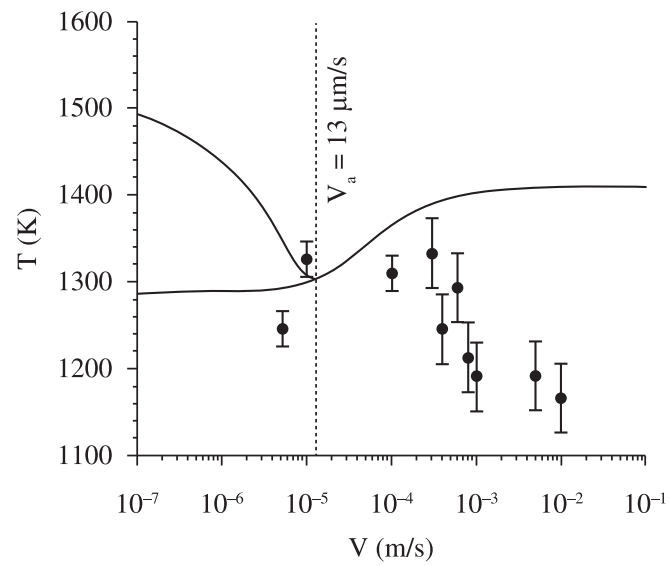

Figure 7. Growth temperatures of austenite in ferrite. Experimental measurements are circles and the calculated interface functions are lines.

Table 4. Calculated values of austenite phase growth during directional solidification.

\begin{tabular}{cc}
\hline $\mathbf{V}(\mu \mathbf{m} / \mathbf{s})$ & $\mathbf{T}(\mathbf{K})$ \\
\hline 5 & 1729.26 \\
10 & 1768.65 \\
100 & 1773.44 \\
\hline
\end{tabular}

which was not actually verified. These results led to believe that the atomic attachment undercooling (Equation 10) took place earlier than expected by the model. This could be understood as a consequence of an interface that is not completely rough, but contain a given number of steps to fix the atoms of the parent phase. Therefore, not all sites at the interface are low-energy sites and some atoms must migrate in the parent phase to find an adequate position. This assumption is also valid for the growth of austenite across grain boundaries, Figure 6. The incoherent side of the precipitates grown faster than the coherent one, since more coherent is the interphase boundaries less low-energy sites are available in the parent phase. It seems that this relationship between incoherency and the austenite growth was also verified during directional growth, since the precipitates growth was not aligned to the solidification growth direction.

A limiting velocity exists for both solidification conditions and solid-state transformations. For the ferriteaustenite reaction, the limiting growth velocity is given by the retained ferrite limit. Once the atoms, attached to the ferrite structure, have not sufficient time to jump into the austenite crystal, the primary phase is retained. The limiting velocity was at $10 \mathrm{~mm} / \mathrm{s}$ for the present alloy, as determined in laser experiments.

The AISI 410S alloy is essentially a ferritic alloy, which can eventually develop a duplex structure when correctly treated. It seems that $1000{ }^{\circ} \mathrm{C}$ is the correct temperature to generate austenite during continuous cooling. However, the temperature drops due to the atomic attachment and the undercooling must to be taking in account for growth speeds between 0.6 and $10 \mathrm{~mm} / \mathrm{s}$. In terms of corrosion, better results can be obtained when the austenite phase can be generated without segregation. If austenite precipitates grow massively the chromium composition will be homogenous everywhere, thus sensitization is avoided. Massive austenite is obtained above $\mathrm{V}_{\mathrm{a}}$, i.e. above $13 \mu \mathrm{m} / \mathrm{s}$, and below the retained ferrite limit, $10 \mathrm{~mm} / \mathrm{s}$.

\section{Conclusions}

The microstructure formation of AISI 410S stainless steel and phase growth modeling were investigated using directional growth and laser melting techniques.

- Thermal and solute convection ahead the solidification interface during the directional solidification led to an additional stabilization of the planar growth mode. The limit of constitutional undercooling was observed as growth rates between 5 and $10 \mu \mathrm{m} / \mathrm{s}$, for a theoretical value of $1.34 \mu \mathrm{m} / \mathrm{s}$. The solidification temperature was measured as $1730 \mathrm{~K}$ for the growth rate of $5 \mu \mathrm{m} / \mathrm{s}$ experiment, and $1750 \mathrm{~K}$ for 10 and $100 \mu \mathrm{m} / \mathrm{s}$ growth rates; 
- Directional growth experiments $(5-10 \mu \mathrm{m} / \mathrm{s})$ produced plate-like and dendritic austenite precipitates in the solid-state. The $100 \mu \mathrm{m} / \mathrm{s}$ directional growth and the laser experiments $(0.3-10 \mathrm{~mm} / \mathrm{s})$ produced plate-like austenite. The appearance of dendrites, with the consequent segregation of the elements, can be prior expected by the current microstructure modeling;

- The ferrite/austenite boundary is not completed rough, as described in the continuous growth model for solidification, since the interface temperature decreased with increased growth speed, Figure 7. At atomic level, not all the interface present low-energy sites for the incoming ferrite atoms, increasing the necessary undercooling for the transformation;

\section{References}

1. Pohl M, Reich W, Ibach A and Wischnewski F. Schweizer Maschinenmarkt. Swiss Association for Materials Science and Technology SVMT. 1998; (5).

2. Harvey PD, editor. Engineering Properties of Steels. Metals Park: American Society for Metals; 1982. 527 p.

3. Boyer HE and Gall TL, editors. Metals Handbook. 10th ed. Materials Park: American Society for Metals; 1990. 2521 p. v. 1: Properties and Selection: Irons, Steels, and HighPerformance Alloys.

4. Krishna BV and Bandyopadhyay, A. Surface modification of AISI 410 stainless steel using laser engineered net shaping, Materials and Design. 2009; 30:1490-1496. http://dx.doi. org/10.1016/j.matdes.2008.08.003

5. Koch GH, Brongers MPH, Thompson NG, Virmani YP and Payer, JH. Corrosion Cost and Preventive Strategies in the United States. McLean: Office of Infrastructure Research and Development; 2001. 773 p. Technical report FHWARD-01-156.

6. Paredes RSC, Borsato KS, Bernardini PAN and Aguila JV. Avaliação da soldabilidade de aços inoxidáveis especiais a ser utilizados na indústria do petróleo. In: Anais do II Congresso Brasileiro de P\&D em Petróleo \& Gás; 2003; Rio de Janeiro. Rio de Janeiro; 2003.

7. Machado JPSE, De Abreu HFG, Sobral AVC and De Sant 'Ana HB. Influência do óleo nacional pesado na corrosão dos aços inoxidáveis. In: Anais do II Congresso Brasileiro de $P \& D$ em Petróleo \& Gás; 2003; Rio de Janeiro. Rio de Janeiro; 2003.

8. McCrink EJ. Seam-welded air hardenable steel constructions. Patent US 10519910. 2004. Avaliable from: <http://patft.uspto. gov/>. Access in: 28/07/2010.

9. Reick W, Pohl M and Padilha AF. O desenvolvimento dos aços inoxidáveis ferríticos-austeníticos com microestrutura duplex - histórico e perspectivas futuras. In: Anais do $47^{\circ}$ Congresso Anual da ABM; 1992; Belo Horizonte. Belo Horizonte; 1992. v. 1 ; p. 557-574.

10. Shek CH, Dong C, Lai JKL and Wong KW. Early-Stage Widmanstätten Growth of the Phase in a Duplex Steel. Metallurgical and Materials Transactions A. 2000;31A:15-19.

11. Aminorroaya S, Reid M and Dippenaar R. Simulation of microsegregation and the solid/liquid interface progression in the concentric solidification technique. Modelling and Simulation
- Massive austenite can be produced at growth rates from 0.3 to $10 \mathrm{~mm} / \mathrm{s}$, and temperatures between 1100 and $1300 \mathrm{~K}$. Since this phase is produced without microsegregation, the structure is less sensitive to corrosion. Above growth velocity of $10 \mathrm{~mm} / \mathrm{s}$, the austenite is not formed anymore, and retained ferrite is verified.

\section{Acknowledgements}

One author (Lima) thanks Professor W. Kurz (Ecole Polytecnique Fédérale de Lausanne - Switzerland) for the guidance during this work. The work was funded by the Commission of Technology and Innovation (Switzerland) and by Swiss Steel Co.

in Materials Science and Engineering. 2011; 19:025003. http://dx.doi.org/10.1088/0965-0393/19/2/025003

12. Hurle DTJ, editor. Bulk crystal growth - Basic techniques. Handbook of crystal growth. Amsterdam: Elsevier; 1994. 658 p. v. 2.

13. Trivedi R, Miyahara H, Mazumder P, Simsek E and Tewari SN. Directional Solidification Microstructures in Diffusive and Convective Regimes. Journal of Crystal Growth. 2001; 222:365-379. http://dx.doi.org/10.1016/S00220248(00)00761-2

14. Lima M and Kurz W. Massive Transformation and Absolute Stability. Metallurgical and Materials Transactions. 2002; 33A:2337-2345. http://dx.doi.org/10.1007/ s11661-002-0357-1

15. Jacot A, Sumida M and Kurz W. Solute trappingfree massive transformation at absolute stability. Acta Materialia. 2011; 59:1716-1724. http://dx.doi.org/10.1016/j. actamat.2010.11.038

16. Gremaud M, Allen DR, Rappaz M and Perepezko JH. The development of nucleation controlled microstructures during laser treatment of Al-Si alloys. Acta Materialia. 1996; 44:26692681. http://dx.doi.org/10.1016/1359-6454(95)00393-2

17. Gill SC and Kurz W. Rapidly solidified Al-Cu alloys: II. Calculation of the microstructure selection map. Acta Metallurgica et Materialia. 1995; 43:139-151.

18. Lippautz S,Zimmermann M, KurzW and Jeglitsch J. Sonderbände der Praktischen Metallographie. 1991; 22:409-412.

19. Lima MSF, Gilgien P and Kurz W. Microstructure Selection in Laser Remelted Fe-C-Si Alloys. Zeitschrift für Metallkunde. 1998; 89:751-757.

20. Fukumoto $\mathrm{S}$ and Kurz W. Solidification phase and microstructure selection maps for $\mathrm{Fe}-\mathrm{Cr}-\mathrm{Ni}$ alloys. ISIJ International. 1998; 38:71-77. http://dx.doi.org/10.2355/ isijinternational.38.71

21. Trivedi R and Kurz W. Dendritic growth. International Materials Reviews. 1994; 39:49-74.

22. Gilgien P and Kurz W. Microstructure selection in binary and ternary alloys. Materials Science and Engineering. 1994; A178:199-201.

23. Smith PM and Aziz MJ. Solute trapping in aluminum alloys. Acta Metallurgica et Materialia. 1994; 42:3515-3525. http://dx.doi.org/10.1016/0956-7151(94)90483-9 
24. Tiller WA, Jackson KA, Rutter JW and Chalmers B. The redistribution of solute atoms during the solidification of metals. Acta Metallurgica. 1953; 1:428-437. http://dx.doi. org/10.1016/0001-6160(53)90126-6

25. Boettinger WJ and Coriell SR. Science and Technology of the Undercooled Melt. Dordrecht; 1986. p. 81. NATO ASI Series 114 .

26. Aziz MJ. Model for solute redistribution during rapid solidification. Journal of Applied Physics. 1982; 53:1158-1169. http://dx.doi.org/10.1063/1.329867

27. Aziz MJ and Kaplan T. Continuous growth model for interface motion during alloy solidification. Acta Metallurgica. 1988; 36 :2335-2347. http://dx.doi. org/10.1016/0001-6160(88)90333-1

28. Aziz MJ. Interface attachment kinetics in alloy solidification. Metallurgical \& Materials Transactions A. 1996; 27A:671-686. http://dx.doi.org/10.1016/0001-6160(86)90056-8

29. Kurz W, Giovanola B and Trivedi R. Theory of microstructural development during rapid solidification. Acta Metallurgica et Materialia. 1986; 34:823-830. http://dx.doi.org/10.1016/00016160(86)90056-8

30. Kurz W and Fisher DJ. Fundamentals of Solidification. 4th ed. Switzerland: Trans Tech Publications; 1998. 247 p.

31. Mullins WW and Sekerka RF. The Stability of a Planar Interface During Solidification of a Dilute Binary Alloy. Journal of Applied Physics. 1989; 35:444-451. http://dx.doi. org/10.1063/1.1713333

32. Huntley DA and Davis SH. Thermal effects in rapid directional solidification: linear theory. Acta Metall. Mater. 1993; 41:20252043. http://dx.doi.org/10.1016/0956-7151(93)90373-Z

33. Carrard M, Gremaud M, Zimmermann M and Kurz W. About the banded structure in rapidly solidified dendritic and eutectic alloys. Acta Metallurgica et Materialia. 1992; 40:983-996. http://dx.doi.org/10.1016/0956-7151(92)90076-Q
34. Kurz W and Trivedi R. Banded solidification microstructures. Metallurgical \& Materials Transactions. 1996; 27A:625-634. http://dx.doi.org/10.1007/BF02648951

35. Turnbull D. On the relation between crystallization rate and liquid structure. Journal of Physical Chemistry. 1962; 66:609613. http://dx.doi.org/10.1021/j100810a009

36. Coriell SR, McFadden GB, Voorhees PW and Sekerka RF. Stability of a Planar Interface During Solidification of a Multicomponent System. Journal of Crystal Growth. 1987; 82:295-302. http://dx.doi.org/10.1016/00220248(87)90317-4

37. Hunziker O. Theory of plane front and dendritic growth in multicomponent alloys. Acta Materialia. 2001; 49:4191-4203. http://dx.doi.org/10.1016/S1359-6454(01)00313-5

38. ThermoCalc thermodynamic database. version J. Sweden: Stockholm Royal Institute; 1994.

39. Iida T and Guthrie RIL. The Physical Properties of Liquid Metals. Oxford: Claredon Press; 1987. 223 p.

40. Koseki T, Matsumiya T, Yamada W and Ogawa T. Numerical modeling of solidification and subsequent transformation of Fe-Cr-Ni alloys. Metallurgical \& Materials Transactions A. 1994; 25A:1309-1321.

41. Porter DA and Easterling KE. Phase Transformations in Metals and Alloys. 2th ed. London: Chapman \& Hall; 1992. 514 p.

42. Lide DR, editor. Handbook of Chemistry and Physics. 78th ed. Florida: CRC Press; 1997. p. 14-36.

43. Brandes EA, editor. Smithels Metals Reference Book. 6th ed. London: Butterworths; 1986.

44. Rosenthal D. The theory of moving sources of heat and its application to metal treatments. Trans A.S.M.E. 1946; 849-866.

45. Lima MSF, Heinemann WA and Kurz W. Final Report Korrosionsbeständiger Bewehrungsstahl. Institut für Baustoffe, Werkstoffchemie und Korrosion; 1998. 7 p. 